\title{
THE EFFECT OF OESTROGEN ON THE FERTILITY OF THE RAT WHEN TRANSFERRED THROUGH THE SEMEN DURING MATING
}

\author{
B. N. BANERJEE* \\ Eppley Research Institute and Department of Obstetrics and Gynecology, \\ University of Nebraska College of Medicine, Omaha, Nebraska
}

(Received 29th January 1968)

\begin{abstract}
Summary. Normal female rats mated with male rats treated with oestradiol-17 $\beta$ for 10 days did not become pregnant. No ova were found on Days 3 and 4 of pregnancy in the oviduct or uteri of these females. It seems that oestrogen was transported via semen during mating in the female reproductive tract and caused rapid transport of ova out of the oviduct and uterus.
\end{abstract}

Greenwald (1961) showed that natural and synthetic oestrogens alter ova transport in female rats and thus prevent pregnancy. Ericsson \& Baker (1966) reported that male rats treated with oestradiol for 8 days were incapable of impregnating normal females. The present study was undertaken to determine why the female rats do not become pregnant following breeding with oestrogentreated males.

Seventy Long Evans male rats, weighing 270 to $300 \mathrm{~g}$, were randomly divided into two equal groups and individually caged. One group of males was injected subcutaneously with $1.0 \mathrm{mg}$ of oestradiol-17B (in $0.5 \mathrm{ml}$ of sesame oil) per rat daily for 10 days, while the control group received a like volume of oil. Vaginal smears were checked every day on a group of adult Long Evans female rats and, on the afternoon of the 10th day of treatment, an oestrous female was placed with each male. The next morning, vaginal smears of the female were checked for spermatozoa. The presence of spermatozoa in the vagina was the only criterion used to indicate a successful mating. After breeding, the females were transferred to separate cages, and the males which did not copulate were re-exposed to other oestrous females. The day spermatozoa appeared in the vaginal smear was designated as the lst day of pregnancy. Some of the females were autopsied on Day 12 of pregnancy, the uterine contents examined, and the number of implantation sites recorded. The other females were killed on Days 1, 2, 3 and 4 of pregnancy, the oviducts and uteri flushed with $0.9 \%$ saline, and the number of ova and stages of cleavage recorded. The body and uterine weights of all the female rats on Days 1, 2, 3 and 4 of pregnancy were also recorded. Uteri from the females and the testes and epididymides from the males were taken from treated and control animals.

* Present address: Woodard Research Corporation, P.O. Box 405, Herndon, Virginia 22070, U.S.A. 
The tissues were fixed in Bouin's solution and stained with haematoxylin and eosin for histological studies.

Ericsson \& Baker (1966) found headless spermatozoa from the vaginal smear of females mated with oestradiol-treated males. In one experiment, we could not confirm this result. Spermatozoa recovered from the vaginal smear of females bred to oestradiol-treated and control males were the same. There were also no morphological differences between the epididymal spermatozoa of treated and control males. This result agrees with Ericsson \& Baker (1966). The uterine and body weights of rats killed on Days 1, 2, 3 and 4 of pregnancy

TABLE 1

BODY AND UTERINE WEIGHTS OF FEMALES ON DIFFERENT DAYS OF PREGNANCY BRED WITH OESTRADIOL-TREATED OR CONTROL MALE RATS

\begin{tabular}{c|c|c|c|c|c|c}
\hline & \multicolumn{3}{|c|}{ Oestradiol } & \multicolumn{3}{c}{ Control } \\
\cline { 2 - 7 } $\begin{array}{c}\text { Day of } \\
\text { pregnancy }\end{array}$ & $\begin{array}{c}\text { No. of } \\
\text { females }\end{array}$ & $\begin{array}{c}\text { Average } \\
\text { body } \\
\text { weight } \\
(\mathrm{g.})\end{array}$ & $\begin{array}{c}\text { Average } \\
\text { uterine } \\
\text { weight } \\
(\mathrm{mg})\end{array}$ & $\begin{array}{c}\text { No. of } \\
\text { females }\end{array}$ & $\begin{array}{c}\text { Average } \\
\text { body } \\
\text { weight } \\
(\mathrm{g})\end{array}$ & $\begin{array}{c}\text { Average } \\
\text { uterine } \\
\text { weight } \\
(\mathrm{mg})\end{array}$ \\
\hline 1 & 4 & 189 & $481^{*}$ & 4 & 191 & 321 \\
2 & 4 & 215 & 316 & 4 & 212 & 289 \\
3 & 4 & 201 & 320 & 4 & 203 & 242 \\
4 & 4 & 190 & 310 & 4 & 200 & 239 \\
\hline
\end{tabular}

* Statistically significant $(P<0.01)$.

TABLE 2

NUMBER AND STAGES OF CLEAVAGE OF OVA RECOVERED FROM THE FEMALES BRED TO OESTRADIOL-TREATED AND CONTROL MALE RATS

\begin{tabular}{|c|c|c|c|c|}
\hline $\begin{array}{c}\text { Day of } \\
\text { pregnancy }\end{array}$ & Treatment & $\begin{array}{l}\text { No. of } \\
\text { females }\end{array}$ & $\begin{array}{c}\text { Average no. } \\
\text { of ova }\end{array}$ & $\begin{array}{l}\text { Stages of } \\
\text { cleavage }\end{array}$ \\
\hline 1 & $\begin{array}{l}\text { Oestradiol } \\
\text { Control }\end{array}$ & $\begin{array}{l}5 \\
4\end{array}$ & $\begin{array}{l}11 \cdot 9 \\
12 \cdot 0\end{array}$ & $\begin{array}{l}\text { 1-cell } \\
1 \text {-cell }\end{array}$ \\
\hline 2 & $\begin{array}{l}\text { Oestradiol } \\
\text { Control }\end{array}$ & $\begin{array}{l}5 \\
5\end{array}$ & $\begin{array}{r}4 \cdot 9 \\
10 \cdot 8\end{array}$ & $\begin{array}{l}\text { 1- and 2-cell } \\
1-\text { and } 2 \text {-cell }\end{array}$ \\
\hline 3 & $\begin{array}{l}\text { Oestradiol } \\
\text { Control }\end{array}$ & $\begin{array}{l}5 \\
5\end{array}$ & $\begin{array}{c}0 \\
10 \cdot 6\end{array}$ & 2- and $\overline{4}$-cell \\
\hline 4 & $\begin{array}{l}\text { Oestradiol } \\
\text { Control }\end{array}$ & $\begin{array}{l}5 \\
4\end{array}$ & $\begin{array}{c}0 \\
10 \cdot 2\end{array}$ & 8-cell \\
\hline
\end{tabular}

are shown in Table 1. The uteri of the females bred to oestradiol-treated males are significantly heavier on Day 1 of pregnancy than those of the females bred to control males. This result indicates that oestrogen had stimulated the female reproductive tract. An increase in the weight of the rat uterus has been used as a biological assay for oestrogens (Lauson, Heller, Golden \& Sevringhaus, 1939).

The number and stages of cleavage of ova recovered from the females mated with oestradiol-treated and control males have been presented in Table 2. It 
seems that alteration of 2-cell ova started on Day 2 of pregnancy in the females mated with oestradiol-treated males. No ova were recovered on Days 3 and 4 of pregnancy from these females, but ova were recovered in the 2- to 8-cell stages of cleavage from the females bred to control males.

These results support the hypothesis of Ericsson \& Baker (1966) that sufficient oestrogen was transferred through the semen during mating in the female reproductive tract and caused rapid transport of ova out of the oviduct and uterus. All females mated with oestradiol-treated males were not pregnant, whereas the females mated with control males were pregnant and had an average of 10.6 implantation sites.

Histological studies of the testes and epididymides did not show any abnormality. Ericsson \& Baker (1966) reported that the lumina of the epididymides contained numerous immature germ cells. However, the uterine sections from the females mated with treated males showed hypertrophy and hyperplasia of both myometrium and endometrium.

\section{REFERENCES}

ERICsson, R. J. \& BAKer, V. F. (1966) Transport of oestrogens in semen to the female rat during mating and its effect on fertility. F. Reprod. Fert. 12, 381 .

GREENWALD, G. S. (1961) The anti-fertility effects in pregnant rats of a single injection of estradiol cyclopentylpropionate. Endocrinology, 69, 1068.

Lauson, H. D., Heller, C. G., Golden, J. B. \& Sevringhaus, E. L. (1939) The immature rat uterus in the assay of estrogenic substances, and a comparison of estradiol, estrone and estriol. Endocrinology, 24, 35. 